\title{
SUSUT MASAK DAN KUALITAS ORGANOLEPTIK BAKSO DAGING SAPI DENGAN PENAMBAHAN TEPUNG SAGU PADA LEVEL YANG BERBEDA
}

\author{
Fera Rosita $^{1}$, Harapin Hafid ${ }^{2}$ dan Rahim Aka ${ }^{2}$ \\ ${ }^{1)}$ Alumnus Fakultas Peternakan Universitas Halu Oleo \\ ${ }^{2)}$ Fakultas Peternakan Universitas Halu Oleo \\ e-mail : harapinhafid@yahoo.co.id
}

\begin{abstract}
ABSTRAK
Penelitian ini bertujuan untuk menghasilkan produk olahan daging dengan kualitas yang lebih baik dan untuk mengevaluasi daya suka konsumen terhadap bakso daging sapi dengan penambahan level tepung sagu yang berbeda melalui uji fisik dan organoleptik telah dilaksanakan di Laboratorium Jurusan Peternakan Fakultas Peternakan Universitas Haluoleo Kendari pada bulan Januari 2013. Penelitian menggunakan Rancangan Acak Lengkap yaitu 3 perlakuan dan 4 ulangan. Perlakuan yang dilakukan adalah penambahan tepung sagu dengan level 15\% (P1), 25\% (P2) dan 35\% (P3). Variabel penelitian meliputi susut masak dan kualitas organoleptik (rasa, aroma, warna, tekstur dan keempukan). Hasil penelitian diperoleh bahwa penambahan tepung sagu 25\% dan 35\% menghasilkan susut masak yang lebih rendah daripada penambahan tepung sagu $15 \%$. Penambahan tepung sagu $15 \%$ dan $25 \%$ menghasilkan rasa dan keempukan yang lebih baik daripada penambahan tepung sagu 35\%. Aroma bakso memiliki rataan skor 3 (cukup disukai), warna bakso memiliki rataan skor 3 (agak abu-abu) dan tekstur bakso memiliki rataan skor 3 yang dikategorikan (agak kasar). Disimpulkan bahwa penambahan level tepung sagu yang berbeda mempengaruhi susut masak $(p<0,01)$, rasa dan keempukan $(p<0,05)$ produk olahan dan tidak mempengaruhi aroma, warna dan tekstur produk olahan.
\end{abstract}

Kata kunci : Bakso, Kualitas fisik, Organoleptik, Tepung sagu

\begin{abstract}
This study was aimed to produce processed meat products with better quality and to evaluated the consumer likes to beef meatballs with the addition of sago flour at different level by physical test and organoleptic test have been implemented in The Laboratory Animal Husbandry Department, Faculty of Animal Sciences, Haluoleo University, Kendari in January 2013. The research using Completely Randomized Design that 3 treatments and 4 replications. The treatment is addition of sago flour with level 15\% (P1), 25\% (P2) and 35\% (P3). Variables of this research include of cooking loss and oraganoleptic test (flavor, aroma, color, texture and tenderness). The result obtained that addition of sago flour $35 \%$ and $25 \%$ result cooking loss lower than addition sago $15 \%$. Addition of sago flour $15 \%$ and $25 \%$ result flavor and tenderness better than addition of sago flour $35 \%$. Meatballs aroma has an median score 3 (well like), meatballs colour has an median score 3 (rather gray) and meatballs texture has an median score 3 (some rough) be concluded that the addition of sago flour at different effect the cooking loss $(p<0,01)$, the flavor and tenderness $(p<0,05)$ processed products and didn't effect aroma, colour and texture processed products.
\end{abstract}

Key words : Meatballs, Physical quality, Organoleptic, Sago flour

\footnotetext{
${ }^{*}$ Corresponding authors
} 


\section{PENDAHULUAN}

Daging merupakan salah satu bahan pangan yang menjadi sumber protein hewani salah satunya adalah daging sapi. Nilai gizi yang terkandung didalam daging lebih banyak bila dibandingkan dengan bahan pangan lainnya. Daging segar merupakan produk yang sangat mudah rusak. Kontaminasi mikroba pada daging segar menjadi faktor utama penyebab kerusakannya. Pengolahan daging menjadi alternatif untuk meningkatkan daya simpan dan daya gunanya sehingga dapat meningkatkan kualitasnya serta jangkauan pemasarannya.

Daging merupakan semua jaringan hewan dan semua produk hasil pengolahan jaringan-jaringan yang sesuai untuk dimakan serta tidak menimbulkan gangguan kesehatan bagi yang memakannya (Soeparno, 2009). Salah satu cara pengolahan daging yang dikenal oleh masyarakat adalah bakso. Bakso sangat populer di Indonesia, karena harga dan macam bakso yang sangat bervariasi mampu memenuhi selera dan daya beli berbagai lapisan masyarakat (Hermanianto dan Andayani, 2002). Bakso adalah suatu produk daging yang dihaluskan, dicampur dengan pati, dibentuk bulatan dan dimasak dengan air panas. Bakso merupakan produk gel dari protein daging (Widyaningsih, 2006).

Bahan pengisi dalam pembuatan bakso adalah tepung berpati. Tepung berpati diantaranya berasal dari tanaman jagung, sagu dan ubi. Bahan pengisi adalah material bukan daging yang ditambahkan pada produk olahan daging. Bahan pengisi memiliki kandungan protein yang rendah dan karbohidrat yang tinggi, sehingga mempunyai daya mengemulsikan lemak dan daya mengikat air yang tinggi (Soeparno, 2009). Pati sagu mengandung amilosa $27 \%$ dan amilopektin $73 \%$. Semakin besar kandungan amilosa, maka pati semakin bersifat kering dan kurang lengket (Wirakartakusumah et al., 1984). Kandungan antara amilosa dan amilopektin berperan dalam membentuk produk olahan. Semakin besar kandungan amilopektin atau semakin kecil kandungan amilosa bahan maka makin lekat produk olahannya (Winarno, 1997).

Pemilihan tepung sagu sebagai bahan pengisi pada pembuatan bakso merupakan upaya menyebarluaskan pemanfaatan bahan berpati selain tapioka dan maizena. Dipilihnya tepung sagu ini karena sudah dikenal masyarakat juga karena harganya yang murah.

Disamping pemilihan daging dan bahan pengisi untuk mendapatkan bakso yang kualitasnya baik maka diperlukan bahan tambahan lain bumbu yang berupa es batu, garam, bawang putih, pala dan merica/lada.

\section{MATERI DAN METODE}

Penelitian ini dilaksanakan di Laboratorium Jurusan Peternakan Fakultas Peternakan Universitas Haluoleo Kendari selama satu bulan (Januari 2013). Peralatan yang digunakan untuk pembuatan bakso terdiri atas penggiling daging (food processor), hot plate, timbangan digital, dandang, pisau, talenan, sendok, loyang, piring dan alat masak lainnya. Bahan yang akan digunakan terdiri atas bahan utama dan bahan pendukung. Bahan utama adalah daging sapi segar dan tepung sagu. Bahan pendukung adalah garam, es batu dan bumbu-bumbu yang meliputi pala, merica (lada) dan bawang putih.

Pembuatan bakso daging sapi ini diterapkan tiga level perlakuan terhadap 
bahan pengisi dengan empat kali ulangan yaitu penambahan bahan pengisi sebanyak 15\%, 25\% dan 35\%. Pembuatan bakso dalam penelitian ini, digunakan daging sapi pre-rigor. Daging tersebut dibersihkan dan dipotong kecilkecil kemudian digiling dengan menggunakan food processor. Pada penggilingan pertama ditambahkan $20 \%$ es batu dari berat daging. Pada penggilingan kedua ditambahkan tepung sagu $15 \%$, 25\% dan 35\% pada masingmasing perlakuan, bawang putih $2 \%$, garam $2 \%$, pala $0,2 \%$, merica (lada) $0,5 \%$ dan gula $0,2 \%$. Dilakukan pembentukan bulatan-bulatan bakso dan direbus selama 15 menit pada suhu $70^{\circ} \mathrm{C}$ selama 15 menit.

Rancangan percobaan yang digunakan untuk penelitian ini adalah Rancangan Acak Lengkap (RAL) yakni menggunakan 3 perlakuan dan 4 kali ulangan. Dengan bahan pengisi terdiri dari 3 level yaitu P1 (15\%), P2 (25\%) dan P3 (35\%). Bahan utama yang digunakan adalah daging sapi dan bahan pendukung lainnya adalah bumbu-bumbu (es batu, garam, pala, merica (lada) dan bawang putih.

Variabel yang akan diamati dalam penelitian ini yaitu susut masak dan uji organoleptik yang meliputi rasa, aroma, warna, tekstur dan keempukan.

Data yang diperoleh akan dianalisis dengan menggunakan analisis ragam (ANOVA) untuk melihat pengaruh perlakuan. Apabila terdapat perbedaan yang sangat nyata $(p<0,01)$, maka dilanjutkan dengan uji Duncan (Gasperz, 1991).

\section{PEMBAHASAN}

\section{Susut Masak Bakso Daging Sapi}

Susut masak merupakan salah satu indikator dari nilai nutrisi suatu produk olahan bahan pangan dan faktor yang akan mempengaruhi nilai ekonomi. Kualitas fisik bakso daging sapi dengan penambahan tepung sagu pada level berbeda dapat dilihat pada Tabel 1 .

Berdasarkan data pada Tabel 1 . menunjukan bahwa penambahan tepung sagu dengan level berbeda memberikan pengaruh yang sangat nyata $(p<0,01)$ terhadap susut masak bakso. Susut masak bakso P3 lebih rendah dibandingkan dengan bakso P2 dan P1. Hasil uji Duncan diperoleh bahwa P1 berbeda sangat nyata dengan P2 dan P3 serta P2 tidak berbeda dengan P3.

Susut masak terendah bakso daging sapi adalah perlakuan penambahan tepung sagu $35 \%$ (P3).

Tabel 1. Susut Masak Bakso Daging Sapi dengan Penambahan Tepung Sagu pada Level yang Berbeda

\begin{tabular}{ccccc}
\hline \multirow{2}{*}{ Kriteria } & \multirow{2}{*}{ Ulangan } & \multicolumn{3}{c}{ Perlakuan } \\
\cline { 3 - 5 } & & $\mathrm{P} 1$ & $\mathrm{P} 2$ & $\mathrm{P} 3$ \\
\hline \multirow{3}{*}{ Susut Masak (\%) } & 1 & 11,33 & 6,00 & 6,67 \\
& 2 & 12,00 & 8,00 & 5,33 \\
& 3 & 15,33 & 10,67 & 6,67 \\
& 4 & 12,00 & 8,00 & 6,27 \\
\cline { 2 - 5 } & Rata-rata & $12,67 \pm 1,80^{\mathrm{a}}$ & $8,17 \pm 1,92^{\mathrm{b}}$ & $6,24 \pm 0,63^{\mathrm{b}}$ \\
\hline
\end{tabular}

Keterangan : Superskrip berbeda pada baris yang sama menunjukkan perlakuan sangat berbeda nyata $(\mathrm{p}<0,01)$ 
Tabel 2. Rataan Skor Nilai Uji Hedonik Bakso Daging Sapi dengan Penambahan Tepung Sagu pada Level yang Berbeda

\begin{tabular}{llll}
\hline \multirow{2}{*}{ Kriteria } & \multicolumn{3}{c}{ Perlakuan } \\
\cline { 2 - 4 } & P1 & P2 & P3 \\
\hline Rasa & $3,27 \pm 0,09^{\mathrm{a}}$ & $3,22 \pm 0,08^{\mathrm{a}}$ & $2,89 \pm 0,28^{\mathrm{b}}$ \\
Aroma & $3,07 \pm 0,21$ & $3,00 \pm 0,14$ & $2,85 \pm 0,62$ \\
Warna & $3,02 \pm 0,18$ & $3,08 \pm 0,22$ & $3,00 \pm 0,28$ \\
Tekstur & $3,00 \pm 0,09$ & $3,07 \pm 0,15$ & $3,15 \pm 0,23$ \\
Keempukan & $3,30 \pm 0,16^{\mathrm{a}}$ & $3,05 \pm 0,13^{\mathrm{ab}}$ & $2,92 \pm 0,24^{\mathrm{b}}$ \\
\hline
\end{tabular}

Keterangan : Superskrip berbeda pada baris yang sama menunjukkan perlakuan berbeda nyata $(p<0,05)$

Hal ini menunjukan bahwa semakin tinggi penambahan level tepung sagu maka susut masaknya akan semakin rendah atau berkurang. Semakin rendah nilai susut masak maka kualitas produk semakin baik karena kehilangan nutrisinya akan lebih sedikit, sebaliknya semakin tinggi nilai susut masak maka kualitas produk akan berkurang. Sesuai dengan pendapat Priwindo (2009) bahwa semakin kecil nilai susut masak maka semakin baik kualitasnya baik dari rasa maupun organoleptiknya termasuk nilai ekonomisnya. Winarno (1997) menambahkan bahwa produk daging olahan sebaiknya mengalami susut masak sedikit mungkin karena susut masak mempunyai hubungan erat dengan rasa maupun organoleptiknya. Soeparno (2009) menyatakan hal sama bahwa daging dengan susut masak yang lebih rendah mempunyai kualitas yang relatif lebih baik daripada daging dengan susut masak yang lebih besar karena kehilangan nutrisinya selama pemasakan akan lebih sedikit.

Tepung sagu merupakan jenis pati yang terdiri dari amilosa dan amilopektin. Semakin tinggi kandungan amilopektinnya maka semakin tinggi daya lengketnya. Menurut Wirakartakusumah et al., (1984) pati sagu mengandung amilosa $27 \%$ dan amilopektin $73 \%$. Tepung sagu memiliki kemampuan menyerap air yang tinggi sehingga susut masak suatu produk olahan semakin rendah. Penambahan tepung sagu sampai dengan level 35\% masih memberikan hasil yang sama dengan penambahan tepung sagu dengan level $25 \%$.

\section{Uji Organoleptik Bakso Daging Sapi}

Pengujian organoleptik adalah pengujian yang didasarkan pada proses pengindraan yaitu kesadaran atau pengenalan alat indra akan sifat-sifat benda karena adanya rangsangan yang diterima alat indra yang berasal dari benda tersebut. Uji ini digunakan untuk mengetahui perbedaan antara produkproduk yang diuji dan mengetahui daya suka konsumen. Rataan skor nilai uji hedonik bakso daging sapi dengan penambahan tepung sagu pada level yang berbeda dapat dilihat pada Tabel 2 .

\section{Rasa}

Rasa merupakan komponen organoleptik yang sangat mendominasi penerimaan konsumen terhadap produk pangan. Respon rasa diterima oleh sensori pada lidah karena adanya partikel yang terlarut dalam air maupun dalam minyak, serta kelarutan protein binding. Rasa menempati peringkat pertama terhadap penerimaan konsumen terhadap bakso. 
Hasil analisis sidik ragam terhadap perlakuan penambahan tepung sagu dengan level terhadap rasa bakso adalah berpengaruh nyata $(p<0,05)$ seperti terlihat pada Tabel 5. Hasil uji Duncan diperoleh bahwa P1 dan P2 nyata lebih baik dibanding P3. Rasa bakso P1 dan P2 nyata lebih baik dibandingkan dengan P3. Artinya, panelis lebih menyukai bakso dengan penambahan tepung sagu pada level $15 \%$ dan $25 \%$. Hal ini disebabkan rasa daging pada bakso P1 dan P2 lebih terasa dibanding P3. Hasil penelitian ini sesuai dengan pendapat Sunarlim (1992) yang menyatakan bahwa konsumen lebih menyukai rasa daging pada bakso dan tidak menyukai rasa pati.

Umumnya ada tiga macam rasa yang sangat menentukan penerimaan konsumen terhadap bakso yaitu, tingkat keasinan, rasa daging dan tingkat kegurihan (Hermanianto dan Andayani, 2002). Menurut Winarno (1997), indra pencicip dapat membedakan empat macam rasa yang utama, yaitu asin, asam, manis dan pahit. Rasa dipengaruhi oleh beberapa faktor yaitu senyawa kimia, konsentrasi dan interaksinya dengan komponen lain.

\section{Aroma}

Hasil analisis sidik ragam terhadap perlakuan penambahan tepung sagu dengan level terhadap aroma bakso adalah tidak berbeda nyata $(p>0,05)$ seperti terlihat pada Tabel 5. Hal ini menunjukan bahwa penambahan tepung sagu dengan level yang berbeda tidak mempengaruhi aroma bakso daging sapi. Aroma bakso daging sapi P1, P2 dan P3 memiliki rataan skor 3,07, 3,00 dan 2,85. Artinya, penambahan tepung sagu pada level yang berbeda tidak berpengaruh terhadap aroma bakso daging sapi atau menghasilkan aroma bakso daging sapi yang sama (cukup disukai).

Aroma bakso dipengaruhi oleh aroma daging dan bumbu-bumbu. Pemasakan dapat mempengaruhi warna, bau, rasa dan produk daging. Menurut Kartika (1988), bahwa aroma bakso yang dihasilkan terutama disebabkan oleh bumbu-bumbu yang digunakan selama prosesing yaitu merica, bawang putih dan pala sehingga menimbulkan aroma yang khas. Fellows (2000) menambahkan, aroma dipengaruhi oleh adanya senyawa volatil serta uap air terlepas selama pemasakan.

\section{Warna}

Hasil analisis sidik ragam terhadap perlakuan penambahan tepung sagu dengan level terhadap warna bakso adalah tidak berbeda nyata $(p>0,05)$ seperti terlihat pada Tabel 5. Hal ini menunjukan bahwa penambahan level tepung sagu yang berbeda tidak mempengaruhi warna bakso daging sapi. Warna bakso P1, P2 dan P3 memiliki rataan skor 3,02, 3,08 dan 3,00. Artinya, penambahan tepung sagu pada level yang berbeda tidak berpengaruh terhadap warna bakso daging sapi atau menghasilkan warna bakso daging sapi yang sama (agak abu-abu).

Warna pada daging yang dimasak umumnya berwarna abu-abu perubahan warna tersebut disebabkan oleh denaturasi globin dan reaksi maillard. Menurut (Lawrie, 2003), selain disebabkan oleh pigmen, perubahan warna pada daging yang dimasak juga akibat hasil denaturasi globin dan dipengaruhi oleh karamelisasi karbohidrat serta reaksi maillard antara gula-gula pereduksi dan asam amino (Lawrie, 2003). 


\section{Tekstur}

Hasil analisis sidik ragam terhadap perlakuan penambahan tepung sagu dengan level terhadap tekstur bakso adalah tidak berbeda nyata $(p>0,05)$ seperti terlihat pada Tabel 5. Hal ini berarti penambahan tepung sagu dengan level berbeda tidak mempengaruhi tekstur bakso daging sapi. Warna bakso dengan penambahan tepung sagu $15 \%, 25 \%$ dan $35 \%$ memiliki rataan skor 3,00, 3,07 dan 3,15 . Artinya, penambahan tepung sagu pada level yang berbeda tidak berpengaruh terhadap tekstur bakso daging sapi atau menghasilkan tekstur bakso yang sama (agak kasar).

Prinyawiwatkul et al. (1997) menyatakan bahwa tekstur dalam produk pangan dipengaruhi kemampuan untuk mengikat air. Koagulasi protein, gelatinisasi kolagen, pelepasan air serta pembengkakan dan gelatinisasi pati merupakan faktor-faktor yang mempengaruhi perubahan tekstur. Menurut Buckle et al. (2009), taraf penambahan bahan pengisi bertujuan untuk memperbaiki elastisitas dari produk akhir dan membentuk tekstur padat.

\section{Keempukkan}

Hasil analisis sidik ragam terhadap perlakuan penambahan tepung sagu dengan level terhadap keempukkan bakso adalah berbeda nyata $(p<0,05)$ seperti terlihat pada Tabel 5. Keempukan bakso P1 dan P2 nyata lebih baik dibanding P3. Artinya, panelis lebih menyukai keempukan bakso dengan penambahan tepung sagu pada level $15 \%$ dan $25 \%$.

Hasil penelitian menunjukan bahwa, semakin rendah penambahan tepung sagu maka nilai keempukannya lebih baik. Hal ini sesuai dengan pernyataan Lukman (2008), semakin sedikit tepung yang ditambahkan kedalam adonan maka kadar air dalam produk olahan tersebut akan semakin tinggi serta kadar protein yang ada dalam produk olahan dapat mengikat air sehingga keempukan akan semakin meningkat.

Salah satu faktor yang mempengaruhi keempukan bakso adalah penggunaan tepung. Menurut Purnomo (1990), semakin tinggi jumlah bahan pengisi yang digunakan menyebabkan meningkatnya kekerasan obyektif bakso. Sebaliknya, kekerasan semakin menurun dengan semakin banyaknya daging. Hal ini karena struktur matriks pati yang lebih rapat dibandingkan protein sehingga struktur pati sulit untuk pecah dan akibatnya bakso dengan pati yang lebih banyak membutuhkan kekuatan yang lebih besar untuk memecah struktur pati.

\section{KESIMPULAN}

\section{Kesimpulan}

Berdasarkan hasil dan pembahasan dapat disimpulkan sebagai berikut :

1. Penambahan level tepung sagu yang berbeda memberikan pengaruh yang sangat nyata $(p<0,01)$ terhadap nilai susut masak dan nyata $(p<0,05)$ terhadap rasa dan keempukan serta tidak nyata $(p>0,05)$ terhadap aroma, warna dan tekstur produk olahan bakso

2. Penambahan tepung sagu sebanyak $35 \%$ dalam produk olahan bakso menghasilkan susut masak yang lebih rendah dibanding dengan penambahan tepung sagu $15 \%$ dan $25 \%$ menghasilkan rasa dan keempukan yang nyata lebih baik daripada penambahan tepung sagu $35 \%$ dan tidak berpengaruh terhadap warna, aroma dan keempukan.

\section{DAFTAR PUSTAKA}


Buckle, K.A., R.A. Edwards, G.H. Fleet dan M. Wooton, 2009. Ilmu Pangan. Terjemahan : $\mathrm{H}$. Purnomo dan Adiono. Universitas Indonesia Press, Jakarta.

Fellows, J.P. 2000. Food Processing Technology, Principles and Practise. 2nd ed.Woodhead Pub. Lim., Cambridge, England.

Gasperz, V., 1991. Metode Rancangan Percobaan. CV Armco. Bandung.

Hermanianto, J. dan R.Y. Andayani, 2002. Studi Perilaku Konsumen dan Identifikasi Parameter Bakso Sapi Berdasarkan Preferensi di Wilayah DKI Jakarta. Teknologi dan Industri Pangan, Bogor.

Kartika, B. 1988. Uji Mutu Pangan. Pusat antar Universitas pangan dan gizi. UGM. Yogyakarta

Lawrie, R. A. 2003. Ilmu Daging. Penerjemah : Aminuddin Parakkasi. Universitas Indonesia Press. Jakarta.

Lukman, D.W., 2008. Daging dan produk olahannya. http://higiene pangan.blogspot.com. [06 Januari 2013].

Prinyawiwatkul, W, Mcwatters, K,H, Benchat, L,R, and Philips, R,D, 1997. Optimizing acceptability of chicken nuggets containing fermented and peanut flour. J. Food Sci. 62(4): 889-893

Priwindo, S. 2009. Pengaruh pemberian tepung susu sebagai bahan pengikat terhadap kualitas nugget angsa. Skripsi. Departemen Peternakan, Fakultas Pertanian Universitas Sumatera Utara. Medan.

Purnomo, H. 1990. Kajian mutu bakso daging, bakso urat dan bakso aci di Bogor. Skripsi. Fakultas tekhnologi Pertanian. Institit Pertanian Bogor, Bogor. http://repository.ipb.ac.id/bitstrea $\mathrm{m} /$ handle/123456789/17588/D02y oc.pdf? sequence $=3$

Soeparno, 2009. Ilmu dan Teknologi Daging. Gadjah Mada University Press, Yogyakarta.

Sunarlim, R., 1992. Karakteristik mutu bakso daging sapi dan pengaruh penambahan natrium klorida dan natrium tripolifosfat terhadap perbaikan mutu. Tesis. Program Pasca Sarjana IPB, Bogor.

Winarno, F.G., 1997. Pangan Gizi, Teknologi dan Konsumen. PT Gramedia. Jakarta.

Widyaningsih, T. D. dan E. S. Murtini. 2006. Alternatif Pengganti Formalin pada Produk Pangan. Trubus Agrisarana, Surabaya

Wirakartakusumah, M.A., M. S. Apriyantono, Ma'arif, Suliantri, D. Muchtadi dan K. Otaka., 1984. Isolatin and Characterization of Sago for Liquid Sugar. Food and Agricultural Organization-badan dan Pengembangan Teknologi, Jakarta. 